\title{
The Role of Political Leadership in Macedonia in Function of EU Integration
}

\author{
Mirvan Xhemaili
}

\begin{abstract}
The dissolution of the former Yugoslavia was associated by destructive interethnic conflicts, by local and regional wars. Macedonia is also closely related to Europe politically and economically. The paper analyzes the role of political leadership on the road to EU integration. The research is one of many efforts that have been undertaken lately on the European Union development, its enlargement policy and the integration of Macedonia in EU. Specifically, this type of research is very important for the Macedonia, having in mind that the country has experienced the worst and the longest transition after the Cold War. The aim of the paper is to identify the main difficulties and challenges that make this process less successful. Macedonia started this journey in 2001 by signing the PSA/MSA. Right after its independence the country has faced many internal and external challenges. The country id undergoing a 25 years' transition period of democratization and consolidation. The road to EU Integration has made the country undergo many reforms in many fields. The country views the process of integration as a strategic objective. The EU union has shown its interest to include the aspiring countries from the Western Balkans in its family. There is a high percentage of citizens for this process. The political leadership has not been responsible for the reforms in the country that have been addressed by EU. The political leadership uses the EU membership as a rhetoric in political campaign rather than doing more for the process, the paper analyzes the rhetoric and the reality by different methodologies. Political leaders should do more for the EU Integration and consider themselves as the only responsible party.
\end{abstract}

Key Words: European Union, Transition Period, Republic of Macedonia, Political Leadership.

\section{Introduction}

The process of enlargement, that is the establishing democracies and economies oriented towards the markets of Central and Eastern Europe began after the fall of the Berlin Wall (1989) and the fall of the Soviet Union. In the last decade of the twentieth century, the countries of this part of Europe intensively progressed the process of democratic consolidation and political and economic integration into the EU. Western Balkans is one of the regions that has experienced the worst and the longest transition after the Cold War. The dissolution of Yugoslavia at the beginning of 1990s was associated by destructive interethnic conflicts, by local and regional wars, and also by political and ethnic accidents. Western Balkans is also closely related to Europe politically and economically. The process of dissolution of former Yugoslavia has fragmentized the Western Balkans in many spheres, starting from the border changes to demographic changes. This process also resulted in creation of new states that changed the geopolitics of the region. The fragmentation was caused by many factors: historical, political, economic, military, geopolitical, and strategic. Also, this development was determined by the political concepts that are leading the region in respect to EU integration. The development of the regional political process has now conditioned and oriented the Western Balkans towards integration in Euro Atlantic structures. After the wars that followed the initial proclamation of independence in several of these countries, a period of consolidation ensued, along with European integration as well as reconciliation efforts. During this period, the EU was engaged in the region through leading a series of peace-keeping missions and paying the lion's share of assistance. This article seeks to identify and analyze the problems and challenges of long transition, the political, economic and social transformations in Macedonia, the process of policy-making in the country, the external and internal factors, the nature and the role of national actors and the political leadership in this process. Macedonia is entering the third decade of efforts for a political transformation, economic and social development with the aim of getting closer to Western democratic models of governance. Currently, the consolidation of democratic institutions, accountability of the system of governance and policy- 
making processes are based on the will of the citizens, always underlying objectives of the country that will help our society be better positioned in the global processes and take advantage of them. In this context, membership in the European Union is regarded as a challenge but also an opportunity to respond to citizens' expectations for a functioning democracy, sustainable development and prosperity. Since the breakup of the former Yugoslavia, respectively of its independence, political leaders and citizens in Macedonia see the future of their country into Euro-Atlantic structures. Macedonia has a European future, not only because of its geographical position, but also for its potential to play a stabilizing role in the region, by a tolerant and multi-ethnic society. Macedonia was established as an independent state in 1991 and it borders with Albania, Kosovo, Serbia, Bulgaria and Greece. Its population consists of two major ethnic groups: Albanians and Macedonians, as well as several other nationalities as Turks, Serbs, Bosnians, Roma, etc. Currently, Macedonia has a status of candidate country for the EU since 2005, and has not managed to move to the next step of the integration process which is the negotiation process. European Commission has recommended seven times each year so far for Macedonia to start the negotiation process, but it hasn't happened by now due to the fact that the country has failed to accomplish the requirements given by the EU. There are numerous challenges that the country is currently dealing with, both internal political challenges and external political challenges.

\section{Historical and Political Context}

\section{Challenges of Macedonia in its domestic politics and foreign policy}

Macedonia's political dynamics has gone through two phases and has been influenced by three main factors.

The first stage starts from the end of 1991 and lasted until the end of 1999. This stage was characterized by the consolidation of the independent state of Macedonia and its international recognition. During this phase as the main objective of the political dynamics of Macedonia were: independence, stability, peace and territorial integrity. Three main factors have contributed to Macedonia's political dynamics, which are as follows: The internal political dynamics; Regional political dynamics, and the dynamics of country's foreign policy.

As regards to the internal political dynamics, Macedonia has its history over the last decade. Immediately after the dissolution of Yugoslavia and the collapse of the communist regime, Albanians and Macedonians formed their own political parties: the Party of Democratic Prosperity which was later followed by the Albanian Democratic Party, VMRO-DPMNE, SDSM, Liberal Party of Macedonia, etc. These political parties are ethnic. They also have the composition, leadership, doctrine and their electorate. The political spectrum in Macedonia since the beginning took the form of a multi-ethnic pluralism rather than to political pluralism. The international community during this phase often referred to Macedonia as "oasis of peace"1 even though they knew well that the country faced major challenges. During the wars in other former Yugoslav republics, both ethnic groups in Macedonia, Albanians and Macedonians even though they had many unresolved issues, were determined to reach a political compromise. This enabled the creation of a relaxed climate between the two ethnic groups in Macedonia. It was important for the country because it averted involvement in the conflict. Regarding the regional political dynamics Macedonia faced with complicated situations over the past decade. Initially, Greece ${ }^{2}$ did not recognize Macedonia's independence because it had and continues to have disputes about Macedonia's constitutional name. Greece considers the name and flag of Macedonia as a matter of its origin, although Macedonia has met all the conditions for starting negotiations with the European Union, but it is faced with the name issue, which is transformed into an "unwritten" criterion that hinders the process of Macedonia's integration into Euro-Atlantic structures. Even today the country faces this challenge, despite continued international efforts for a diplomatic solution between the respective countries. Albania, meanwhile, has followed another foreign policy in relation to Macedonia. Albania was one of the first countries to recognize the independence of Macedonia. And in this way, these two countries established diplomatic relations between the mutual provisions. Bilateral relations developed intensively, including all areas of cooperation.

\footnotetext{
1 Balkan Yearbook of Human Rights 2006, "EU Accession and Human Rights-Consequences, Tendencies and Role of Civil Society, Balkan Human Rights Network, Banja Luka 2006, pg. 105.

2 http://library.fes.de/pdf-files/bueros/skopje/05321/barometer22-2010.pdf

Baromer, Current Events and Political Parties Development in the Republic of Macedonia, Issue N. 22, June 2010, p. 29 (cited by Prof.

Dr Blerim Reka, "The Geopolitics and Techniques of EU Enlargement. Aspect, Brussels, Brussels, Belgium, 2010.)"
} 
Macedonia faced the challenge of Kosovo. In this dimension, Macedonia recognized Kosovo's independence ${ }^{1}$ and the two countries established diplomatic relations. Macedonia's relations with Serbia are disputable. Mainly, the disputed issue is over the Orthodox Church. Macedonia's relations with Bulgaria have a special historical background. Bulgaria has expressed their concerns to the history of Macedonia over the last decade (i.e. towards the Macedonian ethnicity). But Bulgaria was more interested in avoiding problems in the Balkans, focusing instead on its internal reforms and integration into Euro-Atlantic structures. Regarding the dynamics of foreign policy towards Macedonia, it is well known that international community, namely the United Nations, the EU, US, NATO, OSCE2 , were all present in the country, contributing positively to the stability and peace of the country.

The second phase of the political dynamics in Macedonia began in 1999 and still continues. Recognition of its independence from the international community, the internal political compromise from both ethnic (political) groups in the country, the experienced leadership, the and moderate political role by Albania, Bulgaria towards Macedonia and the presence of the international community and its active role, are some factors that helped Macedonia have peace, stability, sovereignty and territorial integrity. This temporary macro-stability was very important not only for the country but also for the entire region, but it did not last long, given the problems that began to emerge in Macedonia with regard to democratization. After the war in Kosovo in 1998, the situation in Macedonia was challenged with various difficult matters. Albanians as the second community in Macedonia, continued to present their continuous demands for human rights and national rights within the state of Macedonia. Macedonia was the first Western Balkan country to sign the Stabilization and Association Agreement with the $\mathrm{EU}^{3}$. In spite of the fact that the SAA was signed the challenges continued in the country, respectively the interethnic challenge. Consequently, the Macedonian side tried to use counter-balance to the Albanian demands and did not react constructively. The dialogue was interrupted and replaced with force. Thus, the situation went out of control and the initiative was taken by the military leaders who formed the National Liberation Army. The political aim of the NLA were Albanian constant demands for human rights and national rights ${ }^{4}$. The political process was replaced with the armed conflict. This situation could have had resulted in the destruction of everything that was reached at that time. But the intervention of the international community stopped the conflict quickly, and as a result brought the parties to negotiations 5 . Consequently, there was an agreement known as the Ohrid Framework Agreement (OFA) (13 August 2001). The implementation of the Ohrid Agreement was one of the essential conditions of Macedonia for European Union membership, even though the same agreement was put into question several times. Ohrid Framework Agreement became a basis for the reforms in the country. Also, the agreement proves the stronger role of the EU in the stabilization phase of the postconflict situation of the country. Therefore, the implementation of the OFA will certainly be considered a facilitating advantage for Macedonia to join the EU. During the second phase of the political dynamics, Macedonia continues with reforms to become an active partner in the further integration in Europe. Therefore, the government made all efforts to become a member of the European Union. However, it relies on the consent of the majority population as well as all relevant political forces in the country. The results of the survey done three years say that $70-75 \% 6$ of the population is in favor of EU membership. The prospects of Macedonia for joining the European Union in the future requires strong political skills that are able to take responsibilities for the reforming process. Macedonia can benefit greatly from EU membership. In spite of the possibility of increasing the living standards and improving the economy, the integration process offers peace and stability for the country as well. Macedonia is a potential member state for EU. The EU has invested constantly in the political stability of Macedonia. EU cannot afford to lose this investment, not only for the sake of Macedonia and other countries of the Western Balkans, but also for the rest of Europe.

\footnotetext{
1 "The relations between Macedonia and Kosovo", Marolov, Dejan \&lvanova, Elena, International Journal of Sciences: Basic and Applied Research (IJSBAR) http:/leprints.ugd.edu.mk/9165/1/The\%20relations\%20between\%20Macedonia\%20and\%20Kosovo\%20$\% 20$ Dejan\%26\%20Elena.pdf

2 Biljana Sekulovska-Gaber, "Megjunarodni Organizacii i Integracii", Forum Shkup, 2003, pg, 201

3 Official Journal of the European Union, Stabilisation and Association Agreement of the Republic of Macedonia, 9 April 2001

${ }^{4}$ Interview given by the President of Democtratic Union of Integration Ali Ahmeti for RTK në 12 Maj 2001

${ }^{5}$ Brunnbauer, U. (2002). The Implementation of the Ohrid Agreement: Ethnic Macedonian Resentments. Center for the Study of Balkan Societies and Cultures (CSBSC)University of Graz, Austria, Issue 2, p. 2

${ }^{6}$ Europe's Macedonian Intervention, Part 1: Assessing EU Behavior By Chris Deliso in

http://www.balkanalysis.com/macedonia/2016/06/13/europes-macedonian-intervention-part-1-assessing-eu-behavior/
} 


\section{Ohrid Framework Agreement - the path to the Europeanization of Macedonia}

The conditions for membership of the EU, continue to serve as a driving force of Europeanization and democratization of the country. The Ohrid Agreement provides a basis for future democratic development of the country ${ }^{1}$. It is clear that the agreement was welcomed for its fragile democracy and the many other problems of Macedonia. So, it was clear that the future of Macedonia will depend significantly on the process of implementation the Ohrid Framework Agreement, due to the fact that this agreement represents a tool for the democratization of the country. A distinguishing characteristic of this agreement that makes it unique and that it is different to other peaceful agreements in the region, is the fact that this peace agreement is designed also as a fundamental document for Reconciliation, Europeanization and Democratization². Today, Euro-Atlantic integration is the most influential contemporary recipe for democracy and peace in the region. EU membership requires successful application of transition and democratic consolidation. All this can be done easily with the full implementation of this OFA, since it democratizes and consolidates the state ${ }^{3}$.

\section{Democratic transformations in Macedonia}

Macedonia, like many other countries, which have recently emerged from a dark history consider being part of the EU.The reason is not only being part of the EU, but also the fact that it is seen as the only possibility for development and progress towards democracy. The process of democratization of the Republic of Macedonia and its accession to Euro-Atlantic structures, has gone through a long period which is known as the transition period ${ }^{4}$. Such conclusion comes from the delay in the process of establishing the first relations with the European Union institutions. Republic of Macedonia right after its independence was immediately intercepted by a series of challenges and obstructions to the recognition of the country by some EU Member States (over the constitutional name issue), as well as to our membership in the UN. Macedonia managed to avoid military conflict with Yugoslavia compared to other countries of the former Yugoslavia 5 . Therefore, Macedonia was one of the first countries of the region to set diplomatic relations with the EU. The establishment of diplomatic relations was the first important step that Macedonia and the European Union established closer relations and so to be familiar with the actual situation in the country and also a preparation for further steps, which the European Union agenda considered for the Western Balkans, and eventually additional criteria for specific candidate countries for the European Union. As for other countries, Macedonia was given concrete steps that were supposed to follow in its integration process ${ }^{6}$. Macedonia was firm to leave the old history behind and move forward to become a democratic country. The country is going through many challenges of democratic transition. The way towards a democratic development in Macedonia should be open to the conditions and factors that determine it, and will serve as the basis for its overall development. Macedonia should be determined politically and constitutionally to follow the path of democratic development, similar to western countries democratic, because only Euro-Atlantic integration can provide a prosperous future for Macedonia. Therefore, the country in the process of prolonged transition, is before a historic challenge in achieving cohesion of society based on the democratic principles and European standards for all its citizens, regardless of ethnicity, religion, beliefs, etc. that can integrate Macedonia into the EU, and will accelerate the historical process of Europeanization of Macedonia in the political, legal, economic and cultural aspects. European integration without doubt represents the most powerful movement of reform processes in Macedonia. Speaking of political leadership and on its influence on the EU integration process, we must focus on political parties that form the government, public administration bodies, and other decision-making institutions in the country. One of the basic features of the political parties in Macedonia is that they are essentially based on ethnic lines. The dominant parties are mono-ethnic, and all ethnic communities are represented by at least one political party, while larger communities with more political parties. In theory, their doctrines are based on the

\footnotetext{
1 Veton Latifi "The Macedonian paradox International long-term presence and the aspirations for the EU integration", EUROZINE, in http://www.eurozine.com/articles/2004-03-22-latifi-en.html, 20 of May 2008.

2 Reka, Blerim, Ten years from the Ohrid Framework Agreement Is Macedonia Functioning as a multi-ethnic state? South East European University, Tetovo, 2011, pg.12-13.

3 Veton Latifi, "Macedonian Challenges in the Process of Democratization and Stabilization" KAS Shkup, 2003, pg. 53.

${ }^{4}$ Malevska, Mirjana, Multiethnic democracy in Macedonia: political analysis and emerging scenarios, New Balkan Politics Issue 13, 2013.

${ }^{5}$ DIFi report, 2010, Direktorate for forvaltning og IKT, How to influence the EU?, An Introduction to the current relations between the Republic of Macedonia and the European Union, Anex 3

${ }^{6}$ Archick, Kristin, L. Morelli, Vincent, European Union Enlargment, Congresional Research Service, 2014
} 
demos, while in practice they are based on ethnos while attracting voters. It can be said that the political system of the country has not taken the opportunity during the 1990s to form parties which will be based on the concept of citizens. The biggest party in Parliament is VMRO-DPMNE (VMRO-Democratic Party for Macedonian National Unity), formed in 1990, and defined as folk-oriented Democrat party. Founded on the historical heritage of VMRO, founded in 1893. It considered its beginnings primarily as a national party. Later, the party redefined its position on the political spectrum, being positioned as center-right. The second biggest political party is SDSM (Social Democratic Union of Macedonia), is a social democratic and main center-left party in Macedonia. It was founded on 20 April 1990. In the Albanian block, the first political party was the Party for Democratic Prosperity, the party was founded in April 1990. Since its beginning, the party had many challenges by internal conflicts, mostly as a consequence to its approach with ethnic questions. As a result, a large number of leading members of the PDP formed new parties. After the first political failure the party lost a huge influence on voters. The next Albanian party in Macedonia was the Democratic Party of Albanians (DPA), which was founded in 1994 as the merger of the Party for Democratic Prosperity (PDP) and the People's Democratic Party (PDP). After the armed conflict in 2001, and the signing of the Ohrid Framework Agreement, the military structure of the NLA (National Liberation Army) was transformed into a political party - the Democratic Union for Integration (DUI), which is the largest Albanian political party in Macedonia. After the 2001, DUI has won all election cycles by a majority of votes. It is a political party which tries to integrate the Albanian community in the state. The activity of these political parties greatly influences the consolidation of democracy in the country. Regardless that all of the political parties in Macedonia which are represented by their political leadership have promised a swift consolidation of the country, and also their commitment to Euro-Atlantic integration, there are still serious challenges that they have to cope with. Macedonia is constantly trying to deal with a political transformation, economic and social development. Only a decade and a half after the declaration of independence in 1991, Macedonia was granted a candidate status for membership in the European Union.. The challenge with the leadership of the country is that the leadership is centralized and decisions taken are more central and authoritarian of style. The inner party democracy is a major challenge that prevents prosperity of political and economic functioning system of the country. In Macedonia, the style of political leadership cannot be regarded as democratic, because it still does not meet the conditions for such functioning. Political leadership in Macedonia is more authoritative. Macedonia is an example of hybrid and conservative democracy, for example. in 2006 the party leader at the head of state offered an enthusiastic reforming program, but in the coming years the new technocratic approach proved different, and as a result the state was paralleled with party: public employment decisions and direct subsidies were controlled by party officials, government and judicial power was used against political enemies, whereas the media came under the strict control of the ruling party ${ }^{1}$. In Macedonia the political leadership is represented in the legislative and executive power of the country that have unlimited impact on the governance and development of the democratic regime as well as economic and social development. The integration of Macedonia in the European Union and NATO is the right strategic orientation for Macedonia, which will guarantee peace, stability, and the prospect of economic development and a higher standard of living ${ }^{2}$. For countries such as Macedonia is not a question of whether or not to integrate into NATO and the European Union, but it is a matter of accelerating this process ${ }^{3}$. There is a general consensus on the integration process for EU not only in the ruling parties in the country but also in other opposition political parties. The political leadership in the country is responsible for the failure in the process of reforms needed for the integration process in the EU. Political leadership of the country uses the integration process more as a rhetoric during the elections and other political speeches. Political parties in the country should closely cooperate with each other for this essential process for the country. Ruling parties in the government should use the citizens' support for this process as a motivation to take the necessary reforms in the country to move forward in the process. if analyzing the progress reports that the EU Commission issues for the country in the process of EU Integration, we can easily see that there are some issues that have been constantly addresses by EU for the country. Among many issues the most serious one are the internal political reforms, and also the disputed issues with the neighboring countries.

\footnotetext{
1 Gjuzelov, Borjan. (2015, June 2). Macedonia's Empty Democracy, New Eastern Europe

${ }^{2}$ Fatmir Besimi, Marrëveshja paqësore e Ohrit dhe sfidat e integrimit në Bashkimin Evropian: ekonomi konkurruese dhe e integruar me shanse të barabarta.

${ }^{3}$ Risteska, M. (2013). The role of the EU in promoting good governance in Macedonia: towards efficiency and effectiveness or deliberative democracy? Nationalities Papers: The Journal of Nationalism and Ethnicity. p. 431-446
} 


\section{Resolving the name dispute a necessity for the continuation of the EU integration process}

The Republic of Macedonia, from the moment of its declaration of independence (1991) obtained a positive opinion from the Arbitration Commission and it was immediately intercepted by a series of challenges and obstructions to the recognition of the country by some EU Member States (over the constitutional name issue), as well as the membership in the UN1. However, in April 1993, the Republic of Macedonia was admitted to the UN as 181 member state, under the temporary reference (FYROM) ${ }^{2}$ and not under its constitutional name. Unfortunately, this question remains an unbridgeable problem until now, and, still, at times slows down and blocks the country's progress towards the EU (and NATO). With the mediation of the international 8 community in September 1995, the Republic of Macedonia and Greece reached a mutual agreement (Interim Agreement), after which they established diplomatic relations and a new perspective for our EU integration appeared. There is a serious need for Macedonia to commit itself in finding a solution with Greece over the name dispute. There is a growing need for a compromise, and the possible compromise would be reached only if both parties were to withdraw from their positions. Macedonia has repeatedly changed its position, which significantly affects negatively on its negotiating position. The name dispute requires a quick solution with the mediation of the international community, which would facilitate the road of Macedonia in the process of integration into Euro-Atlantic structures. It is also needed a more proactive role of the EU in this regard. Government of Macedonia makes every effort possible to involve various actors of the society in the process of integration, thinking that this way the process will be easier. Also, the government considers that the success rate in the process of integration is measured by the implementation of reforms, involvement in decisionmaking of all the main actors, the opposition, civil society, business, interest groups. National institutions take all the necessary measures to have a correct and open relationship with international partners that have been assisting for many years professionally and financially. The country should try institutionally and practically to finalize the process that will strengthen the rule of law and improve the lives of the citizens of the country. Macedonia aspires to be united in diversity in the club of the 28 member states $^{3}$. By inducing European values of peace, opportunity and stability, we must together overcome obstacles on the way to a full membership in the European Union and NATO, through finding solutions that unify us and not divide us; thus encourage the participation of non-division; i.e. promote inclusion rather than exclusion. Additionally, the country should do more on improving the image of the country in the EU, knowing that the process of integration needs the full and unanimous support of the all 28 member states in the EU. So, this process should be regarded as a serious matter, after the wire-tap scandal in 2015, the diplomacy should incorporate various PR teams to do the best in improving the image of the state.

\section{Internal Political issues in the process of EU integration}

One among many challenges for Macedonia is the inter-ethnic relations which remained fragile, and still continue to challenge the state ${ }^{4}$. Ohrid Framework Agreement provides a framework for the protection of multi-ethnic character of society. However, even today there is a lack of trust among ethnic communities ${ }^{5}$, however, in this regard there is a great need for a proactive initiative to promote multi-ethnic society. In recent years, the divisive political culture resulted in two political crisis and failures of the political dialogue. Governing parties also blurred the relationship between the government and the parties, by diminishing confidence in public institutions. But the concern is greater for government control over public institutions and the media. In 2014 the opposition party SDSM boycotted the Parliament for a long period while claiming that the election process in 2014 was not fair and democratic. Therefore, in 20015 the country experienced the worst crisis after its independence because of the wire-tap scandal, which brought massive demonstrations in the country against a government on the ropes after months of damaging wire-tap revelations. The crisis rocking Gruevski's nine-year conservative rule is the worst since Western diplomacy dragged the country from the brink of all-out civil war during an ethnic Albanian insurgency in 2001, promising it a path to European Union and NATO membership. The Prime Minister Nikolla Gruevski has faced a wave of embarrassing revelations against him and his ministers, contained in taped conversations that appear to expose tight government control over journalists, judges and the conduct of elections.

\footnotetext{
${ }^{1}$ Ackermann, Alice, "Making Peace Prevail: Preventing Violent Conflict in Macedonia", Syracuse Universit Press: New York, 2000, p. 12

${ }^{2}$ Atanasov, Tome, Macedonian Path to European Union, Integrating Europe: Traditions, prospects, and challenges 2000, p. 4

${ }^{3}$ Fatmir Besimi, Ten Years of the Enactment of the Stabilisation and Association Agreement, Shkup, 2014. pg.5.

4 The Former Yugoslav Republic of Macedonia, Progress Report, October 2014,

http://ec.europa.eu/enlargement/pdf/key_documents/2014/20141008-the-former-yugoslav-republic-of-macedonia-progress-report_en.pdf ${ }^{5}$ Maleski, Denko. (2006/2007). Macedonia's Road to the European Union. New Balkan Politics. Nr.2006/2007
} 


\section{Political instability and the crisis in 2015-2016}

The political crisis in 2015 and 2016 resulted in a political agreement mediated by the European Union in June/July of last year was aimed at restoring the rule of law in Macedonia, following allegations of criminal activity and abuse of power by senior officials from the government and the ruling VMRO-DPMNE party. The agreement set out a timetable of measures to be taken by the government in addressing many urgent reforms. These included electoral reforms, followed by the organization of early elections in April this year, and the appointment of a Special Prosecutor to investigate the wiretapping scandal that had revealed shocking examples of corruption at the highest levels of government. A year later, with many of the obligations under the agreement yet unfulfilled, the country has continued to sink deeper into crisis. Inter-ethnic tensions remain ubiquitous since the tragic events in May 2015 in the multi-ethnic city of Kumanovo, where 18 people, including eight police officers, were killed - the highest number at any one time since the 2001 conflict - in as yet unexplained circumstances. The lack of any enforcement mechanism deployed by the EU to ensure effective follow-up of all the commitments contained in the political agreement has contributed to an increased sense of impunity by the ruling party. This is nothing new and goes back to the eruption of violence in the Parliament on 24 December 2012, when the opposition MPs and all the media were forcibly ejected from the Chamber. In that case, a belated attempt by the EU (represented by then Commissioner Štefan Füle, together with a delegation of MEPs) to mediate an agreement between the political parties preempted the opposition from carrying out its threat of boycotting the local elections. Four years later, the country now faces a similar scenario but with a much deeper crisis, with the rule of law seriously undermined and the stability of the country under threat.

The early elections scheduled for April this year were postponed to June, and later were postponed again. These repeated delays are due to the failure of the government to implement the much-needed electoral reforms, such as proper vetting of a bloated voters list, guarantees for independent media freedom and an end to intimidation of voters. Eventually, on 20 July 2016 the four political parties agreed:1

\section{Voters list}

The four political parties agree to address the issues with the voters list for these elections in the following way:

1. The electoral code will be amended by 22 July to reflect the agreement below on the voter list.

2. As regards Annex A prepared by SEC relating to cross checks of entries, 171500 persons will be placed on the supplementary part of the voters list and their right to vote is not disputed.

3. As regards Annex B prepared by SEC relating to cross checks of entries, 39502 persons will be published by SEC within 3 days following the adoption of the amendment of the electoral code.

a. The data will be published and the persons concerned can verify with the SEC during 25 days whether they should remain on the voters list.

b. All persons included in Annex B can initiate the verification electronically in accordance with articles $48-51$ of electoral code or in person at local branches of the SEC.

c. Three or more members of the SEC may request an extra scrutiny for any name. In such an instance, the SEC members requesting the extra scrutiny may ask people to appear in person if resident in the country, or via videoconference if they reside abroad. This extra scrutiny will extend for an additional 10 days after the 25 day period. d. Unverified persons will not be included in the voters' list. Those not included will have the additional possibility to register with the SEC during the public review period ahead of the elections.

\section{Media}

1. The AVMS law and the electoral code will be amended within 15 days from the date of this agreement.

2. AAVM will establish an ad hoc body to monitor compliance with media provisions of the electoral code. This ad hoc body will function until the end of the electoral process. This ad hoc body shall be established within 30 days from the date of this agreement.

\footnotetext{
${ }^{1}$ Agreement between the four political parties: 26.08 .2016

http://eeas.europa.eu/delegations/the_former_yugoslav_republic_of_macedonia/press_corner/all_news/news/2016/2016-0720_agreement_en.htm
} 
a. The ad hoc body will be composed of five persons. In consultation with relevant professional organizations the four political parties will select four members of the ad hoc body of whom at least one will be ethnic Albanian. These four persons will select by consensus the fifth member within 15 days.

b. Beginning 100 days before elections, the Council of the AAVM shall follow the recommendation of the newly established department and will initiate the procedures vis-a-vis the media as prescribed by the legislation. The ad hoc body will assess the balanced reporting of media for periods not less than one week.

c. All fines for media outlets in the AAVM Law and electoral code relating to media will be reduced by $50 \%$.

d. The first violation will elicit a warning. The subsequent violations will elicit the new reduced fines.

e. No journalist or media will be fined for expression of opinion. The expression of opinion should be differentiated from reporting information.

f. No media outlet can be shut down based on decisions under the above-mentioned procedure.

3. The four political parties commit to amend the media legislation in line with Urgent Reform Priorities and the Priebe report within 6 months after the elections.

4. In consultation with the other parties, the biggest opposition party will nominate a chief editor of the Public Broadcaster (MRTV) from experts in the field. Provided that the parties confirm that the conditions for elections are in place, the new chief editor will assume his / her functions 100 days before elections.

5. Legal changes will be made to allow 7/24 Albanian channel on MRTV.

\section{Assessment of progress}

By 31 August, leaders of the four political parties will assess whether the above mentioned steps have been completed by which the conditions for holding elections are fulfilled. The leaders will confirm this and the date of elections by a signature.

Government ahead of elections and date of elections

If elections take place in 2016, a new government following the Przino agreement will be voted in by the parliament 100 days before the agreed day of elections.

a. The application of the Law on Internal Affairs will be suspended until 1 January 2017 and the law will limit the number of managerial appointments in the Ministry of Interior to 15. All appointments for prosecution's investigators given to holders of managerial positions in the Ministry of Interior will be annulled and new ones will not be issued to them until the end of the election process.

b. The Government will approve automatically cabinet appointments of the Minister of Interior and horizontal transfers of staff initiated by the Minister of Interior up to $10 \%$ of the number of horizontal transfers based on the average of such transfers in the years 2013 and 2014.

c. The Law on Government will be amended so that the mandate of all ministers and additional deputy ministers appointed pursuant to the Przino Agreement shall end on the day the SEC confirms the official results of the elections.

d. The deputy ministers in the Ministry of Interior and Ministry of Labor and Social affairs will assume the responsibilities of the Ministers until the formation of the new government.

\section{Other issues:}

\section{Special Prosecutor shall be supported}

a) In case Constitutional Court decides SP legislation or its part is unconstitutional, four parties commit to align the legislation with the decision of the Court and to re-establish the office according to decision within five days. The effectiveness, scope and objectives of the SP should be maintained.

b) Four parties call on the Constitutional Court to decide on SP law as soon as possible on the next possible session.

\section{Reforms}

The inclusiveness of the process on reforms and their implementation will be conducted in a working group in the parliament including civil society and experts. 
a. Prioritized adoption of Urgent Reform Priorities and Priebe Recommendations.

b. Amend whistleblower law according to Venice Commission within 6 months.

c. OFA

d. Euro-Atlantic integration.

It remains to see whether this agreement will be implemented, so the country could stabilize its institutions and its system of the state, in this way the integration process will move forward. For a country that was hailed as a success story for EU diplomacy sixteen years ago, following successful mediation in the 2001 inter-ethnic conflict, the fall from grace has been dramatic. It is for the EU to determine whether it wants to go down in history for preserving that legacy or for allowing a candidate country to sink further into lawlessness and rejection of European values.

\section{Conclusion}

The enlargement process towards Western Balkans has been ongoing for quite long period of time and it can be evaluated as successful process which is still in progress. Slovenia (2004) and Croatia (2013) which are already EU member-states, serve as good examples that the integration is also reality for the countries in our region. The EU integration process is a strategic goal for the country in view of democratization and transformation in accordance with the values and principles of a united Europe. The political leadership in the country should be grateful for the trust that voters invested in them, and thus devote maximum efforts to make the needed reforms in the country in the right path of the EU. Therefore, the support of the citizens for the process of integration should serve as a motivation to have a better position in the global processes. However, despite the great interest and a unanimous approval to integration into the EU as a strategic goal, currently, political parties and governance do not show willingness to implement the necessary reforms that will lead toward the European Integration process. Short-dated interests, failures of the open issues of the country, failure of the name dispute with Greece and the non-implementation of the Ohrid Framework Agreement and the political crisis in 2015 and 2016, represent a serious threat for the integration process. Development and integration of the country must go through free elections, fighting the corruption and the organized crime, border security and the rule of law, free market, functional democracy respect and equality for the ethnic communities, as well as the implementation of the PRZINO agreement (June Agreement 2016) which was a compromise agreement between the four main political parties in the country and that was facilitated and mediated by the international community, respectively, USA and EU. Most importantly, the country should implement the agreement reached between the four political parties in the country in July 2016. Successful implementation, would not only stabilize the country but it will also end the political crisis and it would also facilitate the integration process toward the EU. The slow and controversial developments in the recent years in these areas such as the installation of the system of corruption, tolerance against crime and its connection with politics, state capture, the lack of free and fair elections and other obstacles have been the main reason of the process slowdown as for the integration in Euro-Atlantic structures. Every ministry and institution depending on the power they have should build up reports with measurable indicators and should be fully responsible for any progress and delay in carrying out European reforms of integration. The government should undertake all measures for organizational coordination and effective and efficient monitoring of all other institutional activities. In every institution effectively specialized units should function, in order to coordinate and monitor the integration reforms. The entire integration process should be open and the government should welcome the contributions of the opposition, the Constitutional institutions and any other state institution independent of it, civil society, business community, media and its citizens, governmental institutions should welcome the periodic the periodic assessments and the recommendations arising from the European institutions, reflecting on remarks and suggestions seriously and working on their implementation. Governmental institutions should also use the experience accumulated in newly affiliated states or are in the process of membership in the European Union, EU integration is a major effort, which requires the joint work of all institutions, all political parties, as well as the civil society. The charter of EU is clear, implementation of integration reforms which then will change all aspects of political, economic and social life in the country. Country was appreciative to build a state with stable institutions guaranteeing democracy, the rule of law, human rights, respect for and protection of minorities, and a functioning market economy, able to contribute to European development and prosperity. Macedonia needs to make progress in creating a serious political dialogue between political parties and political actors that play a major role in this regard, also reforming the judicial system and administration. The State should also maintain good relations with neighboring countries under the auspices of the United Nations. At the same time the political leadership in the country must enhance the reforms of the judiciary and security structures, proceed with the reforms of the State, local and public administration and build capacities for strategic planning and the utilization of the domestic budget potential, as 
well as putting in place the necessary capacities for the planning, programming and absorption of available EU funds. The political leadership in the country should do more in overcoming all the obstacles to move to the next step which is the negotiation process with EU.

\section{Bibliography:}

[1] Ackermann, Alice, "Making Peace Prevail: Preventing Violent Conflict in Macedonia", Syracuse University Press: New York, 2000, p. 12

[2] Agreement between the four political parties: 26.08 .2016 http://eeas.europa.eu/delegations/the_former_yugoslav_republic_of_macedonia/press_corner/all_news/news/ 2016/2016-07-20_agreement_en.htm

[3] Archick, Kristin, L. Morelli, Vincent, European Union Enlargment, Congresional Research Service, 2014

[4] Atanasov, Tome, Macedonian Path to European Union, Integrating Europe: Traditions, prospects, and challenges 2000 , p. 4

[5] Balkan Yearbook of Human Rights 2006, "EU Accession and Human Rights-Consequences, Tendencies and Role of Civil Society, Balkan Human Rights Network, Banja Luka 2006, pg. 105. http://library.fes.de/pdffiles/bueros/skopje/05321/barometer22-2010.pdf

[6] Baromer, Current Events and Political Parties Development in the Republic of Macedonia, Issue N. 22, June 2010 , p. 29

[7] Blerim Reka, "The Geopolitics and Techniques of EU Enlargement. Aspect, Brussels, Brussels, Belgium, 2010, p.101

[8] Blerim Reka, Ten years from the Ohrid Framework Agreement Is Macedonia Functioning as a multi-ethnic state? South East European University, Tetovo, 2011, pg.12-13.

[9] Biljana Sekulovska-Gaber, "Megjunarodni Organizacii i Integracii”, Forum Shkup, 2003, p, 201

[10] Brunnbauer, U. (2002). The Implementation of the Ohrid Agreement: Ethnic Macedonian Resentments. Center for the Study of Balkan Societies and Cultures (CSBSC) University of Graz, Austria, Issue 2, p. 2

[11] DIFi report, 2010, Direktorate for forvaltning og IKT, How to influence the EU? An Introduction to the current relations between the Republic of Macedonia and the European Union, Anex 3

[12] Fatmir Besimi, Marrëveshja paqësore e Ohrit dhe sfidat e integrimit në Bashkimin Evropian: ekonomi konkurruese dhe e integruar me shanse të barabarta.

[13] Fatmir Besimi, Ten Years of the Enactment of the Stabilisation and Association Agreement, Shkup, 2014. p.5.

[14] Gjuzelov, Borjan. (2015, June 2). Macedonia's Empty Democracy, New Eastern Europe

[15] Interview given by the President of Democtratic Union of Integration Ali Ahmeti for RTK në 12 Maj 2001

[16] Europe's Macedonian Intervention, Part 1: Assessing EU Behavior By Chris Deliso in http://www.balkanalysis.com/macedonia/2016/06/13/europes-macedonian-intervention-part-1-assessing-eubehaviorl

[17] Marolov, Dejan \& Ivanova, Elena, The relations between Macedonia and Kosovo", International Journal of Sciences: Basic and Applied Research (IJSBAR) http://eprints.ugd.edu.mk/9165/1/The\%20relations\%20between\%20Macedonia\%20and\%20Kosovo\%20\%20Dejan\%26\%20Elena.pdf

[18] Malevska, Mirjana, Multiethnic democracy in Macedonia: political analysis and emerging scenarios, New Balkan Politics Issue 13, 2013.

[19] Maleski, Denko. (2006/2007). Macedonia's Road to the European Union. New Balkan Politics. Nr.2006/2007 
[20] Official Journal of the European Union, Stabilisation and Association Agreement of the Republic of Macedonia, 9 April 2001

[21] Risteska, M. (2013). The role of the EU in promoting good governance in Macedonia: towards efficiency and effectiveness or deliberative democracy? Nationalities Papers: The Journal of Nationalism and Ethnicity. $p$. $431-446$

[22] Veton Latifi "The Macedonian paradox International long-term presence and the aspirations for the EU integration", EUROZINE, in http://www.eurozine.com/articles/2004-03-22-latifi-en.html, 20 of May 2008.

[23] Veton Latifi, "Macedonian Challenges in the Process of Democratization and Stabilization" KAS Shkup, 2003, p. 53.

[24] The Former Yugoslav Republic of Macedonia, Progress Report, October 2014,

[25] http://ec.europa.eu/enlargement/pdf/key_documents/2014/20141008-the-former-yugoslav-republic-ofmacedonia-progress-report_en.pdf 